\title{
A Comparison of Swiss and Turkish Pre-service Science Teachers' Attitudes, Anxiety and Self-efficacy Regarding Educational Technology
}

\author{
Hülya Aslan Efe ${ }^{1, *}$, Rıfat Efe ${ }^{2}$, Sait Yücel ${ }^{1}$ \\ ${ }^{1}$ Department of Primary Science Education, Dicle University, Turkey \\ ${ }^{2}$ Department of Biology Education, Dicle University, Turkey
}

Copyright $\mathrm{O} 2016$ by authors, all rights reserved. Authors agree that this article remains permanently open access under the terms of the Creative Commons Attribution License 4.0 International License

\begin{abstract}
In this study, pre-service science teachers' anxiety, self-efficacy and attitudes regarding educational technology were investigated. Given the increased emphasis on educational technology in the classroom, teachers' attitudes, anxiety and self-efficacy regarding educational technology are important. The study was conducted with a total of 726 pre-service science teachers enrolled in teacher education courses in Turkey and Switzerland. Three different questionnaires, with appropriate reliability and validity values, were used to collect data for pre-service science teachers' attitudes, anxiety and self-efficacy regarding education technology. The differences between the pre-service science teachers' attitudes, anxiety and self-efficacy regarding education technology were determined by t-test and one-way ANOVA. The data were analysed based on the dimensions of gender, country and age. Pearson's correlation coefficients were used for the relationships amongst the dependent variables. The findings revealed statistically significant differences amongst the pre-service science teachers' anxiety towards educational technology for all three dimensions (gender, country and age). Also, there were meaningful differences amongst the pre-service science teachers' self-efficacy in the three dimensions. When pre-service science teachers' attitudes towards educational technology were considered, there were only differences in the country dimension. The study revealed that pre-service science teachers had a high level of self-efficacy, an average level of anxiety and a high level of positive attitudes towards educational technology, and it also revealed that self-efficacy, anxiety and attitudes regarding educational technology are correlated.
\end{abstract}

Keywords Educational Technology, Attitude, Self-efficacy, Anxiety

\section{Introduction}

In the era of information and technology, scientific knowledge has increased almost exponentially, and the effects of science and technology significantly affect our everyday lives. The use of technology in classrooms has become important in teaching indigenous users of technology [1], technology has become the basic element in reaching, using, sharing and producing knowledge [2]. Technology has led to changes in school curricula because it presents a powerful tool for developing innovative ways of teaching and learning. From a constructivist perspective, researchers agree that educational technology provides students with a wide range of possibilities for rich experiences and opportunities to practise new ways of learning in the classroom. In education, technology is used to encourage students towards inquiry, enhance communication, produce learning materials and help students to better express themselves [3]. In science education, the use of technology helps students to complete classroom activities and homework faster and more efficiently, support discoveries and experiments, contribute to the production of common knowledge, enhance motivation, visualise processes and claim more responsibility for learning [4]. Text, graphics, sounds, animation, simulations and videos embedded with different learning styles can attract students' attention and add and restructure information through an interactive learning environment that gives students the chance to participate actively in the learning process. The use of technology affects what to teach, how to teach, classroom management and organisation and both teachers' and students' roles and expectations in the classroom. Thus, technology-incorporated classrooms differ from classic classrooms in terms of classroom culture because they have different aims [5]. Technology-incorporated classrooms require teachers to be sufficiently competent to use educational technology. Research reports that teachers 
struggle to keep pace with the use of educational technology, and often, their use of technology is limited to searching a topic on the internet or using Word and PowerPoint in the classroom [6,7]. According to King[8], teachers have a limited use of technology because technology is often seen as frightening, confusing and disappointing, and learning how to use it requires new knowledge and skills that may include complicated processes. Bransford, Brown and Cocking[9] argue that the use of technology in the classroom does not achieve automatic success, which largely depends on the way teachers use it.

One reason educational technology is reluctantly used in the classroom [3], despite the various benefits of educational technology that have been documented by various researchers, is teachers' anxiety towards the use of educational technology $[10,11]$. Teachers with high anxiety levels are often afraid to use or be asked to use technology in their classes. They are afraid of being confronted with technology, and thus, they may prefer not to learn anything and have a negatively affected learning stamina [11].

Self-efficacy is viewed as another important aspect that affects the use of educational technology in the classroom [12]. Self-efficacy refers to one's beliefs in one's capabilities to organise and execute the courses of action required to produce a given outcome [13]. Technology self-efficacy is an individual's judgement about his/her ability to use technology in various areas and cope with different problems that arise in the process. Teachers' self-efficacy is viewed as an important factor for predicting both current behaviour and the effects of treatment on behavioural change. This suggests that decisions to use educational technology in classrooms or in schools are likely to be influenced by teachers' self-efficacy [14].

Pre-service teachers' attitudes towards educational technology are also important when studying educational technology or the use of educational technology because at least some evidence suggests that they can be used as predictors of behaviour [15] or as signs of the potential for effective teaching [16]. There are different definitions of attitudes in the literature, but almost all definitions assert that attitudes are dispositions to behave in certain ways, including reacting with a certain degree of favourableness or unfavourableness to an object, behaviour, person, institution or event [15]. Research on pre-service teachers' attitudes have generally focused on academic achievement $[17,18]$, diversity [19], the environment [20], inclusion [21], gender [22] and teaching [23].

Studies have shown a correlation between attitudes and computers, anxiety and self-efficacy $[24,25]$. Kutluca and Ekici[12] assert that computer self-efficacy and one's attitude towards computers affect each other. Similarly, a study by Zhang and Espinoza[26] finds a strong relationship between self- efficacy perception and attitude towards computers. The study also reports a strong correlation between individuals' computer course test scores, their positive attitude towards computers and their positive self-efficacy perception regarding computers. Studies have also reported a correlation between self-efficacy and anxiety towards using computers $[27,28]$. According to Jawahar and Elango[29], a high degree of computer anxiety leads to negative attitudes towards computer usage. Brosnan[30] suggests that computer anxiety is related to performance outcomes, whereas computer self-efficacy is positively related to successful outcomes. Enhancing future teachers' self- efficacy regarding educational technology, including computers, is likely to lead to lower anxiety and better attitudes in pre-service teachers towards using educational technology in their classrooms. Pre-service teachers with positive attitudes towards educational technology and higher self-efficacy regarding educational technology are more successful in motivating and helping their students have higher academic achievement $[31,32]$.

Different studies have documented teachers', students' and pre-service teachers' attitudes, anxiety and self-efficacy related to educational technology [33,25]. Few studies compare pre-service teachers' anxiety and self-efficacy for and attitude towards technology in different cultural settings [34], in a comparison of Swiss and Chinese pre-service teachers, claims that cultural differences affect their attitudes towards computer technology. Similarly, an earlier study by Omar[35] finds that pre-service teachers from the U.S.A. had more positive attitudes towards computers than pre-service teachers from Kuwait.

The use of educational technology in science teaching is rapidly increasing. In Turkey, the implementation of the Fatih project, which involves making classrooms technology-oriented, including providing Smart Boards for every classroom and a tablet for every student has made it essential for teachers to be good technology users. This project has also changed the way teacher education programs prepare pre-service teachers for their future practices in the classroom. Thus, as future predictors, pre-service teachers' attitudes, self-efficacy and anxiety are important in the development of their educational technology-related skills. Switzerland is one country in which educational technology is used widely in and out of the classroom. The present study compares Swiss and Turkish pre-service science teachers' attitudes, anxiety and self-efficacy related to educational technology. Three main research questions guide this study:

1. Are there differences between Swiss and Turkish pre-service science teachers' self-efficacy regarding educational technology?

2. Are there differences between Swiss and Turkish pre-service science teachers' anxiety regarding educational technology?

3. Are there differences between Swiss and Turkish pre-service science teachers' attitudes towards educational technology?

\section{Methodology of Research}




\subsection{Participants}

Participants from Turkey included 538 (M: 181, F: 357) pre-service science teachers in a science teacher education course at Dicle University, Ziya Gokalp Education Faculty in the 2012-2013 academic year.

The Swiss participants included 188 (M: 37, F: 151) pre-service science teachers in teacher education at St. Gallen Teacher Education University in the 2012-2013 academic year.

\subsection{Data Collection Methods}

The data for attitudes were collected using the "Pre-Service Science Teachers' Attitude towards Educational Technology Scale" developed by Efe[36]. The five-point Likert scale invited pre-service science teachers to respond to the items with "never", "very rare", "sometimes", "often", "always" or "none", "very little", "little", "high", or "very high", according to the nature of the item. The scale included four dimensions that consisted of 48 Likert-type items. The four dimensions on the scale were pre-service teachers' technology background, pre-service teachers' intention to use educational technology in their teaching, pre-service teachers' intention to provide opportunities for their students to use technology in the classroom, and the value of educational technology for learning science. The factor analysis of the scale for the present study revealed that the Kaiser-Meyer-Olkin (KMO) value was .895 , and the Bartlett's Test of Sphericity value was 2,963 (DF: $3655, \mathrm{p}<0.000$ ). ) The four factors of the scale accounted for $25.26 \%, 11.1 \%, 5.76 \%$, and $4.84 \%$ of the variance of the data, for a total of $46.96 \%$. The reliability of the questionnaire was measured through Cronbach's alpha, which was .915 for the entire scale. Cronbach's alphas were $.902, .863, .837$, and .874 for the first, second, third, and fourth variables, respectively.

The data for pre-service science teachers' self-efficacy regarding educational technology were collected through the "Self-Efficacy Perception for Technology Scale", which included 18 Likert-type items developed by Askar and Umay[37]. The factor analysis of the scale demonstrated that the KMO value was .791 , and the Bartlett's Test of Sphericity value was 8,091 (DF: $153, p<0.000$ ). The reliability of the questionnaire was measured through Cronbach's alpha, which was .710 for the entire scale. The levels of self-efficacy used in the study were based on student teachers responses to the items on the scale, one being the lowest and five being the highest.

Pre-service science teachers' anxiety towards educational technology was measured through the "State Anxiety Scale" developed by Spielberg [38]. The scale consists of 20-Likert type items. The Kaiser-Meyer-Olkin (KMO) value was .917, and the Bartlett's Test of Sphericity value was 4,635
(DF: 190, $\mathrm{p}<0.000$ ). The single factor accounted for $42,664 \%$ of the variance. The reliability of the questionnaire was measured through Cronbach's alpha, which was .930 for the entire scale.

\subsection{Data analysis}

Data were analysed using SPSS 18.0. The data were analysed using correlations (Pearson), t-tests, and one-way ANOVA. Pearson's correlation was used to determine whether there were any correlations amongst the variables. T-tests were used to examine the relationships between each country and the gendered responses to the items on the scale. One-way ANOVA was used to determine the differences amongst age groups in relation to their responses to the items.

\section{Results of Research}

The analysis of the data showed a negative correlation (r: -,156) between self-efficacy and anxiety and a positive correlation between the two sub-dimensions of attitude towards educational technology, intention to use technology $(\mathrm{r}:$,248) and intention to provide students with opportunities to use technology (r: ,306). This was interpreted as a one-point increase in a pre-service teacher's self-efficacy regarding educational technology leading to a,156-point decrease in the individual's anxiety towards educational technology. Likewise, a one-point enhancement in a pre-service teacher's self-efficacy regarding educational technology will result in a ,248-point increase in the pre-service teacher's intention to use educational technology and a ,306-point increase in his/her intention to provide students with opportunities to use technology (Table 1). The study did not find any statistically meaningful correlations between self-efficacy and the valuation of educational technology for learning, the third sub-dimension of the attitude variable.

The study also revealed a statistically meaningful, albeit negative, correlation between anxiety and the intention to use educational technology ( $\mathrm{r}:-, 228)$. The intention to provide students opportunities to use technology was r:,- 169 , and the valuation of educational technology for learning was $\mathrm{r}:-, 202$. This finding was interpreted as one point decline in anxiety towards educational technology, resulting in a, 228-point improvement in a pre-service teacher's intention to use educational technology, a ,169-point increase in a pre-service teacher's intention to provide students with opportunities to use technology and a ,202-point increase in his/her belief in the value of educational technology for learning. 
Table 1. The correlations amongst pre-service science teachers' self-efficacy, anxiety, intention and valuation of educational technology

\begin{tabular}{|c|c|c|c|c|c|}
\hline & Self-efficacy & Anxiety & $\begin{array}{l}\text { Intention to use } \\
\text { technology }\end{array}$ & $\begin{array}{l}\text { Intention to provide students } \\
\text { with opportunities to use } \\
\text { technology }\end{array}$ & $\begin{array}{l}\text { Valuation of educational } \\
\text { technology for learning }\end{array}$ \\
\hline Self-efficacy & - &,$- 156^{* *}$ &, $248^{* *}$ &, $306^{* *}$ &, 047 \\
\hline Anxiety &,$- 156^{* *}$ & - &,$- 228^{* *}$ &,$- 169^{* *}$ &,$- 202^{* *}$ \\
\hline Intention to use technology &, $248^{* *}$ &,$- 228^{* *}$ & - &, $666^{* *}$ &, $318^{* *}$ \\
\hline $\begin{array}{l}\text { Intention to provide students with } \\
\text { opportunities to use technology }\end{array}$ &, $306^{* *}$ &,$- 169^{* *}$ &, $666^{* *}$ & - &, $480^{* *}$ \\
\hline $\begin{array}{l}\text { Value of educational technology for } \\
\text { learning }\end{array}$ &, 047 &,$- 202^{* *}$ &, $318^{* *}$ &, $480^{* *}$ & - \\
\hline
\end{tabular}

Table 2. Pre-service science teachers' self-efficacy regarding educational technology in terms of age and gender

\begin{tabular}{|c|c|c|c|c|c|}
\hline Country & Age & $\mathrm{N}$ & Mean & Std. Deviation & ANOVA results \\
\hline \multirow{5}{*}{ Turkey } & $19-22$ & 329 & 2,5723 & ,54435 & \multirow{5}{*}{$\begin{array}{c}\text { F: } .661 \\
\text { Sig: } .576 \\
P>0.05\end{array}$} \\
\hline & $23-25$ & 177 & 2,4144 & ,46636 & \\
\hline & $26-29$ & 26 & 2,4786 & ,49990 & \\
\hline & 30 and over & 6 & 2,2130 & ,67716 & \\
\hline & Total & 538 & 2,4836 & ,51902 & \\
\hline \multirow{5}{*}{ Switzerland } & $19-22$ & 120 & 4,2458 & ,35311 & \multirow{5}{*}{$\begin{array}{c}\text { F: } .784 \\
\text { Sig: } .504 \\
P>0.05\end{array}$} \\
\hline & $23-25$ & 56 & 4,2817 & ,28836 & \\
\hline & $26-29$ & 7 & 4,3810 & ,46749 & \\
\hline & 30 and over & 5 & 4,1000 & ,54348 & \\
\hline & Total & 188 & 4,2577 &, 34442 & \\
\hline Comparison & Country & $\mathrm{N}$ & Mean & Std. Deviation & Result \\
\hline \multirow{2}{*}{ Self- efficacy } & Turkey & 538 & 2.5072 & .46029 & \multirow{2}{*}{$\begin{array}{c}\text { t: }-47.678 \\
\text { sig:. } 000^{*} \\
\mathrm{p}<0.05 \\
\end{array}$} \\
\hline & Switzerland & 188 & 4.2577 & .34442 & \\
\hline Country & Gender & $\mathrm{N}$ & Mean & Std. Deviation & Results \\
\hline \multirow{2}{*}{ Turkey } & Male & 181 & 2.5344 & .47359 & \multirow{2}{*}{$\begin{array}{c}\text { t:-.974 } \\
\text { sig:.330 } \\
\mathrm{p}>0.05\end{array}$} \\
\hline & Female & 357 & 2.4935 & .45345 & \\
\hline \multirow{2}{*}{ Switzerland } & Male & 37 & 4.2568 & .30635 & \multirow{4}{*}{$\begin{array}{c}\mathrm{t}: .018 \\
\text { sig:.985 } \\
\mathrm{p}>0.05 \\
\mathrm{t}: 2.692 \\
\text { sig:.007* } \\
\mathrm{p}<0.05\end{array}$} \\
\hline & Female & 151 & 4.2579 & .35407 & \\
\hline \multirow{2}{*}{ Total } & Male & 218 & 2.8267 & .78841 & \\
\hline & Female & 508 & 3.0179 & .91273 & \\
\hline
\end{tabular}

The strongest correlations were between the intention to use educational technology and the intention to provide students with opportunities to use technology $(\mathrm{r}:, 666)$ and between the intention to provide students with opportunities and the belief in the value of educational technology for learning (r: ,480). This result suggests that a pre-service teacher with strong intentions to use educational technology has a very high possibility of providing his/her students with opportunities to use educational technology. This result is supportive of similar findings in the research conducted by Efe (2011).

Pre-service student teachers' self-efficacy regarding educational technology

This section shows the findings of pre-service science teachers' self-efficacy regarding educational technology in terms of age, gender and county. The study did not reveal any statistically significant differences in the pre-service science teachers' self-efficacy regarding educational technology in terms of age (Table 2). In general, pre-service science teachers had a reasonable level of self- efficacy, and participants in the 19-22 age group had the highest self-efficacy of all groups.

The study did not find any statistically significant differences amongst the Swiss pre-service science teachers in terms of age (Table 2). They had higher self-efficacy regarding educational technology in general than the Turkish pre-service science teachers. The pre-service teachers with the highest self-efficacy regarding educational 
technology were those in the 26-29 age group. Similarly, the study did not reveal any statistically significant differences amongst Turkish pre-service science teachers in terms of age (Table 2). The highest self-efficacy regarding educational technology was shown by the pre-service teachers within the 19-22 age group, followed by the pre-service teachers in the 23-25 age group. The pre-service science teachers with the lowest self-efficacy were the pre-service teachers age 30 and over, though the group included only 6 participants. Although statistically not significant, the pre-service teachers' self-efficacy regarding educational technology decreases with age. This finding might be explained by the fact that younger pre-service teachers are more inclined to use technology than older pre-service teachers.

Table 2 shows pre-service science teachers' self-efficacy regarding educational technology in terms of gender. The study did not find any statistically significant difference between male and female Turkish pre-service science teachers $(p>.05)$. Similarly, there was no significant difference between male and female Swiss pre-service science teachers $(p>.05)$. When all participants were compared, there was a statistically significant difference $(p<.05)$ between male and female student teachers (Table 2). Female student teachers had higher self-efficacy regarding educational technology based on the means. It is evident that Swiss pre-service science teachers show a higher level of self-efficacy regarding educational technology than Turkish pre-service science teachers (Table 2). The differences between the groups are seen as statistically significant $(\mathrm{p}<.05)$.

\section{Pre-service science teachers' anxiety towards educational technology}

In this section, pre-service science teachers' anxiety towards educational technology was analysed in terms of their age groups, gender and country.

The analysis of the data regarding Swiss pre-service science teachers in terms of age did not reveal a statistically significant difference $(\mathrm{p}>.05)$ amongst age groups with respect to their anxiety towards educational technology (Table 3). When means were considered, the highest level of anxiety was shown by the participants in the 26-29 age group, followed by pre-service science teachers in the 30 and over age group. Although statistically not significant, this finding may suggest that younger pre-service science teachers have less anxiety towards educational technology.

The ANOVA results reveal statistically significant differences $(\mathrm{p}<.05)$ amongst the pre-service teachers from Turkey in terms of their anxiety towards educational technology (Table 3).

The ANOVA results for all participants show statistically significant differences $(r<.05)$ amongst the four age groups in terms of their anxiety towards educational technology (Table 3). The post hoc analysis through the Scheffe test reveals that the statistically significant differences $(r<.05)$ are due to the differences between the 19-22 and 23-25 age groups and between the 23-25 and 30 and over age groups (Table 4).

Table 3. Pre-service science teachers' anxiety regarding educational technology in terms of age and gender

\begin{tabular}{|c|c|c|c|c|c|}
\hline Country & Age & $\mathrm{N}$ & Mean & Std. Deviation & ANOVA results \\
\hline \multirow{5}{*}{ Turkey } & $19-22$ & 329 & 2,8085 & ,47391 & \multirow{5}{*}{$\begin{array}{c}\text { F: } 5.565 \\
\text { Sig: .001 } \\
P<0.05\end{array}$} \\
\hline & $23-25$ & 177 & 2,6736 & ,45837 & \\
\hline & $26-29$ & 26 & 2,8000 & ,67926 & \\
\hline & 30 and over & 6 & 3,3000 & 61725, & \\
\hline & Total & 538 & 2,7679 & ,48801 & \\
\hline \multirow{5}{*}{ Switzerland } & $19-22$ & 120 & 2,5667 & ,44312 & \multirow{5}{*}{$\begin{array}{c}F: 1.450 \\
\text { Sig: } .230 \\
P>0.05\end{array}$} \\
\hline & $23-25$ & 56 & 2,6446 & ,52281 & \\
\hline & $26-29$ & 7 & 2,9071 &, 51513 & \\
\hline & 30 and over & 5 & 2,7200 & ,49573 & \\
\hline & Total & 188 & 2,6066 & , 47360 & \\
\hline Comparison & Country & $\mathrm{N}$ & Mean & Std. Deviation & Result \\
\hline \multirow{2}{*}{ Anxiety } & Turkey & 538 & 2.7679 & .48801 & \multirow{2}{*}{$\begin{array}{c}\mathrm{t}: 3.931 \\
\text { sig:.000* } \\
\mathrm{p}<0.05\end{array}$} \\
\hline & Switzerland & 188 & 2.6066 & .47360 & \\
\hline Country & Gender & $\mathrm{N}$ & Mean & Std. Deviation & Results \\
\hline \multirow{2}{*}{ Turkey } & Male & 181 & 2.8334 & .52265 & \multirow{2}{*}{$\begin{array}{c}\text { t: }-2.224 \\
\text { sig: } 027^{*} \\
\mathrm{p}<0.05\end{array}$} \\
\hline & Female & 357 & 2.7347 & .46673 & \\
\hline \multirow{2}{*}{ Switzerland } & Male & 37 & 2.7459 & .60855 & \multirow{4}{*}{$\begin{array}{c}\text { t:- }-2.012 \\
\text { sig:.046* } \\
\text { p }<0.05 \\
\text { t:-3.358 } \\
\text { sig:.001* } \\
\text { p }<0.05\end{array}$} \\
\hline & Female & 151 & 2.5725 & .42987 & \\
\hline \multirow{2}{*}{ Total } & Male & 218 & 2.8186 & .53769 & \\
\hline & Female & 508 & 2.6865 & .46167 & \\
\hline
\end{tabular}


Table 4. Scheffe test for Turkish pre-service science teachers' anxiety towards educational technology in terms of age

\begin{tabular}{|c|c|c|c|c|c|c|}
\hline (I) age & (J) age & \multicolumn{2}{|c|}{ Mean Difference (I-J) } & Std. Error & \multicolumn{2}{|r|}{ Sig. } \\
\hline & $23-25$ & ,13486* & & 04464 & & 029 \\
\hline \multirow[t]{3}{*}{$19-22$} & $26-29$ & ,00849 & & 09823 & & 1,000 \\
\hline & 30 and over &,- 49151 & & ,19855 & &, 107 \\
\hline & $19-22$ &,$- 13486^{*}$ & &, 04464 & &, 029 \\
\hline \multirow[t]{3}{*}{$23-25$} & $26-29$ &,- 12637 & & 10103 & & ,668 \\
\hline & 30 and over &,$- 62637 *$ & & 19995 & & 021 \\
\hline & \multicolumn{5}{|c|}{ *. The mean difference is significant at the 0.05 level. } & \\
\hline & Source of Variance & $\begin{array}{l}\text { Sum of } \\
\text { squares }\end{array}$ & $\begin{array}{c}\text { Degree of } \\
\text { freedom }(\mathrm{df})\end{array}$ & $\begin{array}{c}\text { Mean } \\
\text { Squares }\end{array}$ & F-value & $\mathrm{p}$ \\
\hline \multirow{4}{*}{ Turkey } & Between groups & 3.261 & 3 & 1.087 & & \\
\hline & Within groups & 387.133 & 534 & .725 & 1.499 & .214 \\
\hline & Total & 390.394 & 537 & & & \\
\hline & Between groups & .139 & 3 & .046 & & \\
\hline \multirow[t]{3}{*}{ Switzerland } & Within groups & 62.874 & 184 & .342 & .136 & .939 \\
\hline & Total & 63.014 & 187 & & & \\
\hline & Between groups & 2.128 & 3 & .709 & & \\
\hline \multirow[t]{2}{*}{ General } & Within groups & 481.084 & 722 & .666 & 1.604 & .363 \\
\hline & Total & 483.211 & 725 & & & \\
\hline
\end{tabular}

Table 6. Pre-service science teachers' intentions to use educational technology in their classrooms in terms of gender

\begin{tabular}{|c|c|c|c|c|c|}
\hline & & $\mathrm{N}$ & Mean & Std. Deviation & Results \\
\hline \multirow[t]{2}{*}{ Turkey } & Male & 181 & 4.2238 & .87865 & $\mathrm{t}: .469$ \\
\hline & Female & 357 & 4.2603 & .84012 & $\begin{array}{c}\text { sig:.639 } \\
p>0.05\end{array}$ \\
\hline \multirow[t]{2}{*}{ Switzerland } & Male & 37 & 3.7590 & .45124 & $\mathrm{t}: 309$ \\
\hline & Female & 151 & 3.7919 & 60910 & $\begin{array}{c}\text { sig:.758 } \\
p>0.05\end{array}$ \\
\hline \multirow[t]{2}{*}{ Total } & Male & 218 & 4.1449 & .8395 & t:.-360 \\
\hline & Female & 508 & 4.1211 & .8070 & $\begin{array}{c}\text { sig: } .719 \\
p>0.05\end{array}$ \\
\hline
\end{tabular}

Table 7. Pre-service science teachers' intentions to use educational technology in their classes in terms of country

\begin{tabular}{ccccc}
\hline & $\mathrm{N}$ & Mean & Std. Deviation & Results \\
\hline Turkey & 538 & 4.2132 & .6656 & $\mathrm{t}: 6.561$ \\
Switzerland & 188 & 3.8423 & .6719 & $\mathrm{sig}: 000$ \\
$\mathrm{p}<0.05$ & $\mathrm{p}$ \\
\hline
\end{tabular}

The analysis of the data shows statistically significant differences $(p<.05)$ between the genders in terms of their anxiety towards educational technology (Table 3). The present study found that female participants had less anxiety towards educational technology in each country and in total. Swiss pre-service science teachers have less anxiety towards educational technology than Turkish pre-service science teachers based on the mean scores.

Pre-service science teachers' attitudes towards educational technology

Pre-service science teachers' attitudes towards educational technology are analysed under three sub-headings: their intentions to use educational technology in their classrooms, their intentions to provide opportunities for their students to use educational technology and their valuations of educational technology for learning science.

Pre-service science teachers' intentions to use educational technology in their classrooms

The study did not reveal statistically significant differences amongst age groups in terms of the pre-service teachers' intentions to use educational technology in their classrooms (Table 5). Age was not a differentiating factor for either Turkish or Swiss pre-service science teachers' intentions to use educational technology in the future in their teaching.

Table 6 shows that there are no statistically significant differences $(p>.05)$ between males' and females' responses in terms of their intentions to use educational technology in 
their classrooms when they become teachers. When gender is considered, there are no significant differences in Swiss and Turkish students' intentions to use educational technology. The mean scores suggest that both groups of pre-service science teachers have a high intention to use educational technology in their classrooms (Table 6).

Pre-service science teachers' attitudes towards using educational technology in the future yielded a statistically significant difference $(\mathrm{p}<.05)$ in terms of country (Table 7).

The mean difference shows that, although both groups have a high intention to use educational technology in their classes, Turkish pre-service science teachers have higher scores in their responses for their intentions to use educational technology in their classrooms in the future.

Pre-service science teachers' intentions to provide opportunities for students to use educational technology.

When pre-service science teachers were compared in terms of their intentions to provide opportunities for students to use educational technology, the study did not find any statistically significant differences amongst the groups in terms of age ( $>$.05; Table 8). Age did not appear to be a significant differentiating factor when examining pre-service science teachers' intentions to provide opportunities for students to use educational technology for both the Swiss and Turkish participants.

The present study does not find statistically significant differences ( $>$.05) between male and female pre-service science teachers in terms of their intentions to provide opportunities for students to use educational technology when the Swiss and Turkish participants were analysed separately (Table 8 ).

The mean scores show that in both groups, male pre-service science teachers have slightly higher intentions to provide opportunities for students to use educational technology. When all pre-service science teachers are considered, a statistically significant difference is seen between male and female pre-service science teachers.

Table 8. Pre-service science teachers' intentions to provide opportunities for students to use educational technology during science classes in terms of their age groups

\begin{tabular}{|c|c|c|c|c|c|c|}
\hline & Source of Variance & $\begin{array}{l}\text { Sum of } \\
\text { squares }\end{array}$ & $\begin{array}{c}\text { Degree of freedom } \\
\text { (df) }\end{array}$ & $\begin{array}{c}\text { Mean } \\
\text { Squares }\end{array}$ & F-value & $\mathrm{p}$ \\
\hline \multirow{3}{*}{ Turkey } & Between groups & 3.352 & 3 & 1.117 & & \\
\hline & Within groups & 428.682 & 534 & .803 & 1.392 & .224 \\
\hline & Total & 432.034 & 537 & & & \\
\hline \multirow{3}{*}{ Switzerland } & Between groups & 1.346 & 3 & .449 & & \\
\hline & Within groups & 98.496 & 184 & .535 & .838 & .475 \\
\hline & Total & 99.842 & 187 & & & \\
\hline \multirow{3}{*}{ General } & Between groups & 5.631 & 3 & 1.877 & & \\
\hline & Within groups & 594.879 & 722 & .824 & 2.278 & .078 \\
\hline & Total & 600.509 & 725 & & & \\
\hline
\end{tabular}

Table 9. Pre-service science teachers' intentions to provide opportunities for students to use educational technology in science classes in terms of gender

\begin{tabular}{|c|c|c|c|c|c|}
\hline & & $\mathrm{N}$ & Mean & Std. Deviation & Results \\
\hline \multirow[t]{2}{*}{ Turkey } & Male & 181 & 4.0260 & .88383 & \multirow{2}{*}{$\begin{array}{c}\text { t:-1.070 } \\
\text { sig:.285 } \\
p>0.05\end{array}$} \\
\hline & Female & 357 & 3.9384 & .90334 & \\
\hline \multirow[t]{2}{*}{ Switzerland } & Male & 37 & 3.3649 & .36985 & \multirow{2}{*}{$\begin{array}{c}\text { t:.-918 } \\
\text { sig:.360 } \\
p>0.05\end{array}$} \\
\hline & Female & 151 & 3.2417 & .79359 & \\
\hline \multirow[t]{2}{*}{ Total } & Male & 218 & 3.9138 & .9278 & \multirow{2}{*}{$\begin{array}{c}\mathrm{t}:-2.485 \\
\text { sig: } .013 * \\
\mathrm{p}<0.05\end{array}$} \\
\hline & Female & 508 & 3.7313 & .8558 & \\
\hline
\end{tabular}

Table 10. Pre-service science teachers' intentions to provide opportunities for students to use educational technology during science classes in terms of country

\begin{tabular}{ccccc}
\hline & $\mathrm{N}$ & $\mathrm{Mean}$ & Std. Deviation & Results \\
\hline Turkey & 538 & 3.9678 & .8969 & $\mathrm{t}: 9.666$ \\
Switzerland & 188 & 3.2660 & .7306 & sig: $.000^{*}$ \\
$\mathrm{p}<0.05$ & \\
\hline
\end{tabular}


The study reveals that with respect to providing opportunities for their students to use educational technology, both the Swiss and Turkish pre-service science teachers have high scores (Table 9). However, they do not display statistically significant differences $(\mathrm{p}<.05)$ in terms of gender. When all students are considered, there are statistically significant differences between male and female pre-service science teachers. In both groups, male pre-service science teachers score higher, which likely leads to statistically significant differences when the total number of pre-service science teachers is considered.

When the pre-service science teachers are compared according to country, the Turkish pre-service science teachers have higher scores in their attitudes towards the value of educational technology for learning (Table 10). The differences are statistically significant $(\mathrm{p}<.05)$.

Pre-service science teachers' responses to the value of educational technology for learning science

In this sub-section, the findings and discussion related to pre-service science teachers' attitudes towards the value of educational technology are provided in regards to age, gender and country variables.

Table 11 shows that, in terms of age group, there are no statistically significant differences $(p<.05)$ between pre-service science teachers from Switzerland and Turkey.

Table 12 shows the comparison of student teachers' attitudes towards the value of educational technology for learning science in relation to gender. The table does not reveal statistically significant differences between males and females in terms of their attitudes towards the value of educational technology. Gender does not appear to be a differentiating factor for Swiss and Turkish pre-service science teachers in this respect. When the mean scores are examined, it is evident that, in both groups of pre-service science teachers, female students have a more positive attitude towards the value of educational technology in learning (Table 12). However, this difference is not statistically significant.

Table 11. Pre-service science teachers' responses to the value of educational technology for learning science in terms of age

\begin{tabular}{|c|c|c|c|c|c|c|}
\hline & Source of Variance & $\begin{array}{l}\text { Sum of } \\
\text { squares }\end{array}$ & $\begin{array}{l}\text { Degree of } \\
\text { freedom }(\mathrm{df})\end{array}$ & $\begin{array}{c}\text { Mean } \\
\text { Squares }\end{array}$ & F-value & $\mathrm{p}$ \\
\hline \multirow{3}{*}{ Turkey } & Between groups & 1.873 & 3 & .624 & & \\
\hline & Within groups & 236.066 & 534 & .442 & 1.412 & .238 \\
\hline & Total & 237.938 & 537 & & & \\
\hline \multirow{3}{*}{ Switzerland } & Between groups & .721 & 3 & .240 & & \\
\hline & Within groups & 83.712 & 184 & .455 & .528 & .663 \\
\hline & Total & 84.433 & 187 & & & \\
\hline \multirow{3}{*}{ General } & Between groups & 1.977 & 3 & .659 & & \\
\hline & Within groups & 339.559 & 722 & .470 & 1.402 & .241 \\
\hline & Total & 341.537 & 725 & & & \\
\hline
\end{tabular}

Table 12. Pre-service science teachers' responses to the value of educational technology for learning science in terms of gender

\begin{tabular}{|c|c|c|c|c|c|}
\hline & & $\mathrm{N}$ & Mean & Std. Deviation & Results \\
\hline \multirow[t]{2}{*}{ Turkey } & Male & 181 & 4.1776 & .70677 & \multirow{2}{*}{$\begin{array}{c}\mathrm{t}: .884 \\
\text { sig:.377 } \\
\mathrm{p}>0.05\end{array}$} \\
\hline & Female & 357 & 4.2313 & .64407 & \\
\hline \multirow[t]{2}{*}{ Switzerland } & Male & 37 & 3.8127 & .70255 & \multirow{2}{*}{$\begin{array}{c}\text { t:.298 } \\
\text { sig:.766 } \\
\text { p }>0.05\end{array}$} \\
\hline & Female & 151 & 3.8496 & .66645 & \\
\hline \multirow[t]{2}{*}{ Total } & Male & 218 & 4.1157 & .71769 & \multirow{2}{*}{$\begin{array}{c}\text { t:.039 } \\
\text { sig: .969 } \\
\text { p }>0.05\end{array}$} \\
\hline & Female & 508 & 4.1178 & .67319 & \\
\hline
\end{tabular}

Table 13. Pre-service science teachers' responses to the value of educational technology for learning science in terms of gender

\begin{tabular}{ccccc}
\hline & $\mathrm{N}$ & Mean & Std. Deviation & Results \\
\hline Turkey & 538 & 4.2132 & .6656 & $\mathrm{t}: 6.561$ \\
Switzerland & 188 & 3.8423 & .6719 & $\mathrm{~s}<0.00$ \\
\hline
\end{tabular}


When the pre-service teachers are compared in relation to their countries, significant differences $(p<.05)$ were found in their attitudes towards the value of educational technology for learning (Table 13). The mean scores show that, although both student groups display a positive attitude towards the value of educational technology for learning, Turkish pre-service science teachers have a more positive attitude.

\section{Discussions}

The study revealed that there were not any statistically significant differences in the pre-service science teachers' self-efficacy regarding educational technology in terms of age and gender. This result is in line with the findings of Tuncer and Tanas[39], who did not report any significant differences amongst pre-service teachers in terms of age. Previous research on the topic generally does not report any statistically significant difference in self-efficacy in terms of gender [24]. By contrast, Erdemir, Bakırcı \& Eyduran[40] found that female teachers had a higher level of self-efficacy than male teachers in using educational technology. Durnell, Haag \& Laithwaite[41], when comparing Scottish pre-service teachers with Romanian pre-service teachers, found that Scottish pre-service teachers were better in beginning skills, whereas Romanian pre-service teachers were better in advanced skills. Li and Kirkup[42] found that English pre-service teachers enjoyed using computers more than Chinese pre-service teachers, but Chinese pre-service teachers had a higher level of self-efficacy regarding computers. Similarly, in a much earlier study, Makrakis[43] compared Japanese pre-service teachers with Swedish pre-service teachers in terms of computer self-efficacy. The study revealed differences between the two cultures. Swedish pre-service teachers had higher level of self-efficacy regarding computer usage than Japanese pre-service teachers.

The findings of the study also displayed that while there was differences among Turkish science student teachers' anxiety to educational technology, there was not any statistically significant among science student teachers' in terms of student teachers' anxiety toward educational technology. Different studies have focused on anxiety towards educational technology, particularly computers $[44,45]$. Studies on anxiety towards technology in terms of age differences have yielded different results. Kobili, Togia \& Malliari[46]. found that older people have more anxiety towards computers. The study by Tsai, Lin \& Tsai[47] did not find any relationship between age and anxiety towards educational technology. The present study supports the previous finding that age differences do not appear to be important in anxiety towards educational technology.

The present study found that gender differences were statistically significant in terms of anxiety towards educational technology. Over the years, studies of gender differences in anxiety towards educational technology have reported different results. Dupin-Bryant [48] reported that male participants had more computer anxiety than female participants. By contrast, Durndell and Haag [49], Abdelhamit [50] and Todman[51] found that male participants had less anxiety towards computers than female participants. Tekinarslan [34] reported similar anxiety levels in the two genders towards technology. The present study found that female participants had less anxiety towards educational technology in each country and in total. The analysis of the data shows statistically significant differences between the genders in terms of their anxiety towards educational technology. Swiss pre-service science teachers have less anxiety towards educational technology than Turkish pre-service science teachers based on the mean scores. Harris, Kemmerling \& North[52], in an intercultural comparative study, found that Thai and Tanzanian participants had a higher level of computer anxiety than participants from Hong Kong. Tanzanian pre-service teachers had the highest level of computer anxiety compared to Tanzanian, Chinese, Malaysian, Thai, New Zealander and Hong Kong students. Yaghi \& Abu-Saba [53], (1998) found that French- and Arabic-speaking Lebanese teachers had higher levels of computer anxiety than English-speaking Lebanese teachers. In a comparative study, Tekinarslan[34] found that Turkish university students had a higher level of anxiety towards computers than Dutch university students.

The findings of the study revealed that science student teachers have positive attitude toward educational technology. When the literature is examined, it is evident that several studies report a positive pre-service teacher attitude towards educational technology [54,55]. Similarly, Baki, Yalçınkaya, Özpınar \& Uzun[56]. report positive pre-service teacher attitudes towards using technology in learning. The present study, also, supports previous studies that found that pre-service teachers have positive attitudes towards providing opportunities for their students to use educational technology in the classroom [57,36]. Efe[36] did not find any statistically significant differences between the genders in terms of their intentions to provide opportunities for their students to use educational technology. Educational technology generally contributes to a positive learning environment [58,59], and the results show that pre-service science teachers are well aware of this fact.

\section{Conclusions}

In this study, pre-service science teachers' anxiety, self-efficacy and attitudes regarding using educational technology are examined. The study is a cross-cultural investigation; it focuses on and compares pre-service science teachers from Switzerland and Turkey. The Turkish government regards the use of educational technology in the classroom as an essential part of educating young generations, and it is spending a considerable amount of 
money through an ambitious project called 'Fatih', which includes providing a tablet for all students in compulsory education and interactive Smart Boards for each classroom. Science is a subject that has the most potential for using educational technology. Therefore, it is crucially important for future teachers to be able use educational technology in and out of the classroom. To educate pre-service science teachers during teacher education courses to use educational technology, it is important to understand their anxiety, self-efficacy and attitudes towards educational technology.

The study revealed that pre-service science teachers had a high level of self-efficacy, an average level of anxiety and a high level of positive attitudes towards educational technology, and it also revealed that self-efficacy, anxiety and attitudes regarding educational technology are correlated. The study found that age was not a differentiating factor for self-efficacy and attitudes, whereas it was an important factor for anxiety towards educational technology only for the Turkish participants. In the same vein, gender was only a differentiating factor for anxiety for the Turkish pre-service science teachers. The Swiss participants had a higher level of self-efficacy and a lower level of anxiety than the Turkish pre-service science teachers. The Turkish pre-service science teachers had better attitudes towards educational technology.

\section{REFERENCES}

[1] K. Robinson. The Element, Penguin Books, London. 2009.

[2] S. Topsakal. Fen ve Teknoloji Öğretimi. Ankara: Nobel Yayın Dağıtım. 2005

[3] Y. Baek, J. Jung, B. Kim. What makes teachers use technology in the classroom? Exploring the factors affecting facilitation of technology with a Korean sample, Computers \& Education, v.50, i.1, 224-234. 2008.

[4] S. Hennessy. Integrating Technology into Teaching and Learning of School Science: a Situated Perspective on Pedagogical Issues in Research, Studies in Science Education, 42:1, 1-48.2006

[5] G.M. Kleiman. Myths and realities about technology in K-12 schools. The Online Journal of the Leadership and the New Technologies Community, 14: 1-8. 2000

[6] R. Kozma. Technology, Innovation, and Educational Change: A Global Perspective. International Society for Technology in Education, Sayfa 36. Eugene, OR. 2003.

[7] P.A. Ertmer. Teacher pedagogical beliefs: The final frontier in our quest for technology integration. Education Tech. Research Dev., 53(4): 25-39. 2005.

[8] P.K. King. Educational technology professional development as transformative learning opportunities. Computers and Education, 39(3): 283-297.2002.

[9] J. Bransford, A. Brown, R. Cocking. How People Learn: Brain, Mind, Experience, and School. Washington, DC: National Academic Press. 2000.
[10] Gürcan, A. (2003). The effect of learning strategy on computer anxiety. Computers in Human Behavior, 19: 565-578.

[11] J.M. Myers, R. Halpin. Teachers' attitudes and use of multimedia technology in the classroom: Constructivist-based professional development training for school districts. Journal of Computing in Teacher Education, 18(4): 133-140.2002.

[12] T. Kutluca, G. Ekici. Investigation of prospective teachers' attitudes and self-efficacy perceptions related to computer-assisted instruction. Hacettepe University Journal of Education, 38: 177-188. 2010.

[13] A. Bandura. Social Cognitive Theory: An Agentic Perspective. Annu. Rev. Psychol. 52:1-26. 2001.

[14] T. Teo. Modelling Technology Acceptance in Education: A Study of Pre-Service Teachers. Computers \& Education, 52: 302-312. 2009.

[15] J. Jaccard, H. Blanton. The origins and structure of behavior: Conceptualizing behavior in attitude research. In D. Albarracín, B. T. Johnson, \& M. P. Zanna (Eds.), Handbook of attitudes and attitude change. Mahwah, NJ: Erlbaum. 2005.

[16] A.J. Stronge. Age-related differences in strategies: Investigating problem solving in a complex real-world task. Unpublished master's thesis, Georgia Institute of Technology, Atlanta. 2002.

[17] S. Szyjka, F. Mumba, K. Wise. Cognitive and Attitudinal Predictors Related to Line Graping achievement among Elementary Pre-service Teachers, Journal of Science Teacher Education, pp. 1-16. 2010

[18] P.O. Yara. Relationship between teachers' attitude and students' academic achievement in mathematics in some selected senior secondary schools in Southwestern Nigeria, European journal of Social Sciences, 11(3), 364-369. 2009.

[19] M.A. Garmon. Changing pre-service teachers' attitudes/beliefs about diversity: what are the critical factors? Journal of Teacher Education, 55 (3), 201-213. 2004

[20] G. Liarakou, C. Gavrilakis. The contribution of ICTs in Education for Sustainable Development. In: E. Avgerinos (Ed.), The Contribution of New Technologies to a Qualitative Tertiary Education, Athens: Garamond Print, pp. 129-144. 2009.

[21] S. Pearson. Using Activity Theory to understand prospective teachers' attitudes to and construction of special educational needs and/or disabilities. Teaching and Teacher Education, 25, 559 -568. 2009.

[22] F.T. Erden. A course on gender equity in education: Does it affect gender role attitudes of pre-service teachers? Teaching and Teacher Education, 25(3), 409-414. 2009.

[23] T.C. Liu. Web-based Cognitive Apprenticeship Model for Improving Pre-service Teachers' Performances and Attitudes towards Instructional Planning: Design and Field Experiment. Educational Technology \& Society, 8 (2), 136-149. 2005.

[24] Ş. Pamuk, D. Peker. Turkish pre-service science and mathematics teachers' computer related self-efficacies, attitudes, and the relationship between these variables. Computers and Education, 53: 454-461.2009.

[25] A.O. Agbatogun. Self-concept, computer anxiety, gender and attitude towards interactive computer technologies: a 
predictive study among Nigerian teachers. International Journal of Education and Development Using Information and Communication Technology, 6(2): 2-14. 2010.

[26] Y. Zhang, S. Espinoza. Relationships among computer self-efficacy, attitudes toward computers, and desirability of learning computing skills. Journal of Research on Computing in Education, 30 (4): 420-36.1998

[27] D.J. Ayersman, W.M. Reed. Effect of learning styles programming, and gender on computer anxiety. Journal of Research on Computing in Education, 28(2): 148-161. 1995

[28] P.J. Blignaut, T. Mc Donald, J. Tolmie. The Influence of Experience, Culture and Spatial Visualization Ability on Users' Attitudes and Anxiety Towards Computer Use. Editörler; E. J. Szewczak \& C. R. Snodgrass, Human Factors in İnformation Systems, 269-280, Idea Group Publishing, Hershey, PA, USA. 2002.

[29] I.M. Jawahar, B. Elango. The effects of attitudes, goal setting, and self-efficacy on end user performance. Journal of End User Computing, 13(2): 40-45. 2001.

[30] M.J. Brosnan. The impact of computer anxiety and self-efficacy upon performance, Journal of Computer Assisted Learning, 14: 223-234. 1998

[31] E. McGrail. Teachers, technology and change: English teachers' perspectives. Journal of Technology and Teacher Education, 13(1): 5-24. 2005.

[32] R. Christanse. Effects of technology integration education on the attitudes of teachers and students. Journal of Research on Technology in Education, 34(4): 411- 434.2002.

[33] N.D. Oye M.C. Obi, T.N. Mohd., A. Bernice. Guidance and Counseling in Nigerian Secondary Schools: The Role of ICT, I.J. Modern Education and Computer Science, 2012, 8, 26-33.2012

[34] E. Tekinarslan. Computer anxiety: A cross-cultural comparative study of Dutch and Turkish university students. Computers in Human Behavior, 24: 1572-1584.2008

[35] M.H. Omar. Attitudes of college students towards computers: a comparative study in United States and the Middle East. Computers in Human Behavior, 8: 249-257.1992

[36] R. Efe. Science student teachers and educational technology: experience, intentions, and value. Educational Technology \& Society, 14 (1): 228-240.2011

[37] P. Aşkar, A. Umay. İlköğretim matematik öğretmenliği ögrencilerinin bilgisayarla ilgili özyeterlik algısı. Hacettepe Üniversitesi Eğitim Fakültesi Dergisi, 21: 1-8.2001.

[38] C.D. Spielberger. Manual for the State-Trait Anxiety Inventory. Palo Alto, CA: Consulting Psychologists Press. 1983

[39] M. Tuncer, R. Tanaş. Eğitim fakültesi öğrencilerinin bilgisayar öz-yeterlik algılarının değerlendirilmesi. Adiyaman Üniversitesi Sosyal Bilimler Enstitüsü Dergisi, 4(6): 222-232. 2011

[40] N. Erdemir, H. Bakırcı, E. Eyduran. Öğretmen adaylarının teknolojiyi kullanabilme özgüvenlerinin tespiti. Türk Fen Eğitimi Dergisi. 6(3): 99-108. 2009.

[41] A. Durndell, Z. Haag, H. Laithwaite. Computer self-efficacy and gender: A cross cultural study of Scotland and Romania.
Personality and Individual Differences, 28: 1037-1044.2000.

[42] N. Li, G. Kirkup. Gender and cultural differences in Internet use: A study of China and the UK, Computers \& Education, 48: 301-317. 2007.

[43] V. Makrakis, Cross-cultural comparison of gender differences in attitude towards computers in Japan and Sweden. Scandinavian Journal of Educational Research, 36: 275-287. 1992

[44] N. Bozionelos. Computer anxiety: relationships with computer experience and prevalence. Computers in Human Behavior, 17: 213-224. 2001.

[45] J. King, T. Bond, S. Blandford. An investigation of computer anxiety by gender and grade. Computers in Human Behavior, 18: 69-84.2002.

[46] S. Korobili, A. Togia, A. Malliari. Computer anxiety and attitudes among under-graduate students in Greece. Computers in Human Behavior, 26: 399-405. 2010.

[47] C.H. Tsai, S.S.J. Lin, M.J. Tsai. Developing an Internet Attitude Scale for high school students. Computers \& Educat ion, 37: 41-51. 2001.

[48] P.A. Dupin-Bryant. Reducing computer anxiety in adult microcomputer training. Journal of Extension, 40(5). 2002.

[49] A. Durndell, Z. Haag. Computer self-efficacy, computer anxiety, attitudes towards the internet and reported experience with the internet, by gender, in an east European sample. Computers in Human Behavior, 18: 521-535. 2002.

[50] I.S. Abdelhamid. Attitudes toward computer: A study of gender differences and other variables, Journal of the Social Sciences, Vol 30(2) 2002, 285-316.2002.

[51] J. Todman. Gender differences in computer anxiety among university entrants since 1992. Computers and Education, 34: 27-35.2000.

[52] S.R. Harris, R.L. Kemmerling, N.M. North. Brief virtual reality therapy for public speaking anxiety. Cyberpsychology and Behavior, 5(6), 543-550. 2002.

[53] H.M. Yaghi, M.B., Abu-Saba. Teachers' computer anxiety: an international perspective. Computers in Human Behaviour, 14(2): 321-336. 1998

[54] S. Kahraman. Eğitim fakültesi öğrencilerinin bilgisayar kullanımı ve eğitimde bilgisayar kullanımı hakkındaki görüşleri. 5th International Computer \& Instructional Technologies Symposium, 22-24 September 2011, Firat University, Elazığ- Turkey. 2011.

[55] M. Kahyaoğlu H.C. Çelik, S. Yangın. İlköğretim fen bilgisi, matematik ve sınıf öğretmenliği bölümü öğretmen adaylarının teknolojiye yönelik tutumları. Ulusal Sinıf Öğretmenliği Kongresi, 14-16 Nisan 2006, Gazi Üniversitesi-Ankara. 2006.

[56] A. Baki, H.A. Yalçınkaya, İ. Özpınar, S.Ç. Uzun. İlköğretim matematik öğretmenleri ve öğretmen adaylarının öğretim teknolojilerine bakışlarının karşılaştııılması, Turkish Journal of Computer and Mathematics Education, 1(1): 67-85. 2009

[57] S. Usun. Undergraduate students' attitudes on the use of computers in education. Turkish Online Journal of Educational Technology, 3(2): 62-70.2004. 
[58] R. Başarıcı, A. Ural. Bilgisayar öğretmen adaylarının bilgisayar destekli eğitime yönelik tutumları. International Online Journal of Educational Sciences, 1(1): 165-176.2009
[59] E. Oğuz, A.M. Ellez, G.Ö. Akamca, T.İ. Kesercioğlu, G. Girgin. Early childhood teacher candidates' attitudes towards computer and computer assisted instruction. Illkögretim Online, 10(3): 934-950. 201 